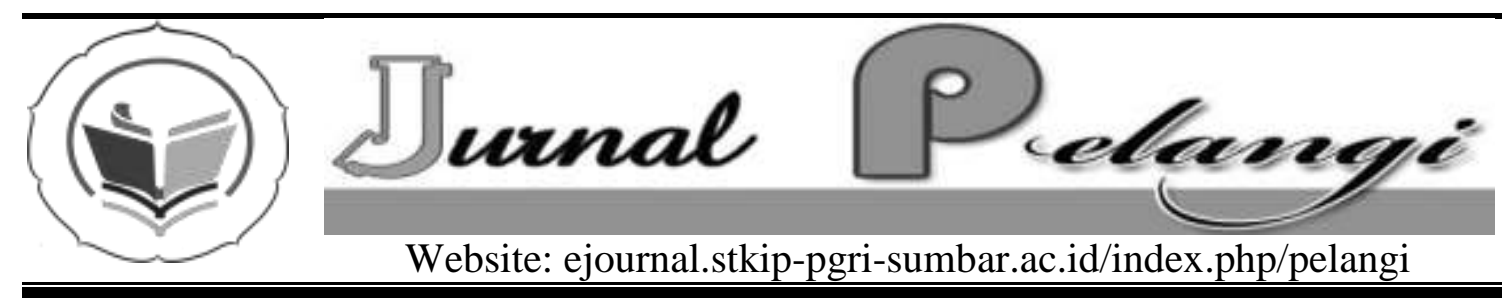

\title{
KOMPOSISI PLANKTON YANG TERDAPAT DI DANAU KANDIS, DESA SALAK, KOTA SAWAHLUNTO
}

\author{
Nursyahra \& Abizar
}

\section{INFO ARTIKEL}

Diterima :

Disetujui:

Kata Kunci:

Key words : Plankton,

Kandis Lake

\begin{abstract}
Research about composition of plankton in Kandis Lake have been the survival descriptive method. The result have be composed of plankton in Kandis Lake much group to phytoplankton. Phytoplankton those genus were: Lyngbia,Spirulina, Oscillatoria, Merismopedia, Oedogonium, Closterium, Cosmarium, Pediastrum, Desmidium, Cladophora, Coscinodiscus, Trepsinoe, Meloisira, Surirella, Gyrosigma, Navicula, Cymbella, Fragillaria, Synedra and Euglena.Zooplankton those genus were : Moina, Cylops, Diaptomus, Nauplius, Oroperla,Astramoeba, Difflugia, Branchinus, Chephalodella, Filinia, Lepadella, Lycane, Notolcha, Proales, Tetramastix and Testudinella.
\end{abstract}

\section{PENDAHULUAN}

Sumber daya lahan mengalami Danau adalah cekungan besar dipermukaan bumi yang digenangi oleh air, bisa tawar atau asin yang seluruh cekungan tersebut dikelilingi oleh daratan. Danau dipandang sebagai suatu sungai yang sangat lebar dan dalam serta mengalir lambat dibagian dasar. Perairan danau cenderung diam, karena itu dinamakan perairan lentik. Agar dapat dianggap sebagai suatu danau, suatu badan air harus memiliki tepian gundul (tak bervegetasi) yang disapu oleh gelombang (Welch cit Tyas 2006). Apabila ditinjau dari struktur dalam cekungan danau, ada dua zona kedalaman yang umum disebutkan, yaitu zona litoral dan pelagik. Zona litoral membentang dari tepian, tepat diatas pengaruh gelombang sampai kedalaman dimana cahaya nyaris tidak cukup bagi pertumbuhan tumbuhan air berakar. Pada danau-danau yang dalam, area diluar pengaruh tepian atu dasar disebut sebagai zona limnetik atau pelagik (Tyas, 2006) Seperti yang diduga, penyebaran biota didalam suatu danau ditentukan terutama oleh keadaankeadaan abiotik, terutama lapisanlapisan. Pada suatu danau terdapat berbagai jenis organisme, seperti plankton, perifiton, benthos, nekton, dan makrofita. Plankton adalah organisme 
yang terapung atau melayang layang di dalam air yang pergerakannya relatif pasif, perifiton adalah organisme air yang tumbuh atau hidup pada permukaan benda yang berada dalam air, seperti tumbuhan, kayu, batu, dan lainlain, nekton adalah organisme yang mempunyai kemampuan untuk bergerak, sehingga mereka tidak bergantung pada arus yang kuat atau gerakan air yang disebabkan oleh angin, benthos adalah organisme yang hidup didasar badan air (Odum, 1988) Penyebaran plankton didalam danau diatur oleh serangkaian pengubah yang banyak, seperti kepadatan air, suhu, intensitas cahaya, waktu, dan fotosintesis (Anwar, 1984).

$$
\text { Air danau mempunyai }
$$

kandungan-kandungan kimia yang dapat mempengaruhi kehidupan organisme yang terdapat didalam danau tersebut, organik yang berasal dari air hujan, dan nitrogen. Faktor-faktor ynag mempengaruhi komposisi fitoplankton pada suatu perairan dapat berupa suhu, kadar oksigen terlarut, intensitas cahaya dan faktor faktor abiotik lainnya pada kedalaman air yang berbeda.

Fitoplankton

merupakan

tumbuhan air yang melayang hanyut dalam air serta mampu berfotosintesis. Untuk dapat melakukan fotosintesis, Fitoplankton membutuhkan cahaya matahari. Jika suatu perairan keruh, maka keadaan tersebut dapat mengahambat cahaya matahari menembus air, sehingga fotosintesis terganggu (Nyibakken, 1992). Keberadaan Fitoplankton merupakan komponen utama dalam siklus rantai makanan dan salah satu indikator dalam memantau badan perairan. Fitoplankton merupakan tumbuhan renik mulai dengan ganggang bersel satu sampai ganggang bersel banyak (Djuhanda,1980).
Dari proses pembentukan danau Kandis ini diperkirakan bahwa air danau bersifat asam. Hal ini dianggap wajar terjadi karena danau tersebut terbentuk dari bekas tambang batu bara terbuka, dimana salah satu dampak yang mungkin timbul dari areal bekas tambang batu bara adalah air asam tambang. Tidak semua jenis fitoplankton dapat bertahan dengan kondisi air yang asam. Ada fitoplankton yang dapat bertahan pada suasana basa, dan ada fitoplankton yang dapat bertahan pada suasana asam, contohnya Cyanophyta. Selain itu kualitas danau ini nantinya juga akan dipengaruhi oleh pembusukan materi organik yang ada didasar danau dan juga pencemaran yang berasal dari limbah yang dibuang melalui Sungai Batang Ombilin yang mengalir ke Danau Kandih (Ediyarman, 2003 ).

Berdasarkan wawancara penulis dengan salah seorang pegawai yang bekerja di Badan Lingkungan Hidup Kota Sawahlunto pada tanggal 16 Mei 2010 diketahui bahwa Danau Kandih juga dicemari oleh limbah buangan dari Sungai Batang Ombilin. Menurut hasil pengujian yang dilakukan di Danau Kandih menunjukkan bahwa Danau Kandih mengandung senyawa Carbon yang tinggi.

Pada tahun 2009 Danau Kandih pernah dimanfaatkan oleh penduduk setempat sebagai areal pembudidayaan ikan, namun ikan-ikan tersebut mengalami kematian massal. Hal ini sudah dua kali terjadi yaitu pada bulan Januari dan bulan Maret 2009, semenjak itu budidaya ikan din Danau Kandih dihentikan. Danau ada yang terbentuk secara alami dan ada yang terbentuk akibat aktifitas manusia atau secara buatan. Danau kandih yang terletak di Desa Salak, Kota Sawahlunto merupakan salah satu danau yang terbentuk akibat aktifitas manusia. Danau Kandih terbentuk pada tanggal 25 


\section{Jurnal Pelangi}

April 2003, mempunyai luas 12 ha dan kedalamannya ada yang sampai $175 \mathrm{~m}$ (Anonimus, 2010).

Danau Kandih pada awalnya merupakan areal penambangan batu bara terbuka yang belum sempat direklamasi, namun karena tingginya aktifitas penambangan membuat cerukan semakin dalam hingga menyerupai sebuah danau. Pembatas areal tambang dengan Sungai Ombilin yang semakin dangkal menyebabkan air dari Sungai Ombilin mengalir memenuhi cerukan tersebut sehingga menyerupai sebuah danau. Danau yang terletak di Kecamatan Talawi ini sekarang merupakan salah satu objek wisata di Kota Sawahlunto.

Berdasarkan latar belakang diatas penulis tertarik untuk meneliti Komposisi Plankton Di Danau Kandih, Desa Salak, Kota Sawahlunto. Berdasarkan latar belakang dan batasan masalah yang telah dikemukakan diatas, maka rumusan masalah dalam penelitian ini adalah

1. Jenis plankton apa saja yang ditemukan di Danau Kandih, Desa Salak, Kota Sawahlunto ?

2. Bagaimana Komposisi Fitoplankton yang terdapat di Danau Kandih, Desa Salak, Kota Sawahlunto ?

3. Danau yang terbentuk secara buatan akibat aktifitas penambangan seperti danau kandih menyisakan beberapa unsur kimia yang dapat mencemari danau tersebut dan dapat berpengaruh terhadap organisme yang ada didalamnya.

4. Batubara adalah salah satu bahan bakar fosil yang dapat terbakar yang unsurunsur utamanya terdiri dari Carbon, Oksigen dan Hidrogen. Komposisi batubara hampir sama dengan komposisi jaringan kimia tumbuhan, keduanya mengandung unsur utama yang terdiri dari unsur $\mathrm{C}$, $\mathrm{H}, \mathrm{O}, \mathrm{N}, \mathrm{S}$ dan P. Batubara terbentuk dari jaringan tumbuhan yang telah mengalami coalification. Salah satu dampak dari kegiatan pertambangan adalah munculnya air asam tambang.

Pembentukan air asam tambang ini terjadi karena adanya proses oksidasi yang terjadi pada batuan yang mempunyai kandungan pyrite setelah mengalami kontak dengan oksigen baik yang terdapat diair maupun yang terdapat diudara. Air tersebut kemudian akan mengalami perubahan ph menjadi 2-3. Air asam tambang ini juga dicirikan dengan rendahnya $\mathrm{ph}$ dan tingginya senyawa logam seperti besi, alumunium dan mangan. Plankton adalah kelompok - kelompok organisme yang hanyut bebas dalam air dan sangat lemah daya renangnya. Kemampuan berenang organisme organisme planktonik demikian lemah sehingga mereka sama sekali dikuasai oleh gerakan-gerakan air. Ini berlawanan dengan nekton yaitu hewan-hewan laut yang gerakan-gerakan renangnya cukup kuat untuk melawan arus. Plankton dibagi menjadi 2 golongan yaitu Fitoplankton dan Zooplankton (Nybakken,1992).

Penyebaran plankton didalam air tidak sama pada kedalaman air yang berbeda. Hal ini disebabkan karena adanya perbedaan suhu, kadar oksigen, intensitas cahaya dan faktor abiotik lainnya dikedalaman air yang berbeda (Suin,2002). Menurut Nontji (1993), plankton adalah organisme yang hidup melayang atau mengambang dalam air. Fitoplankton sebagai tumbuhan yang mengandung pigmen klorofil mampu melaksanakan reaksi fotosintesis, dimana air dan karbondioksida dengan 
adanya sinar surya dan garam-garam hara dapat menghasilkan senyawasenyawa organik seperti karbohidrat. Fitoplankton tersebut sebagai produsen primer merupakan pangkal rantai pakan dan merupakan pedoman yang mendukung kehidupan biota lainnya.

Plankton adalah organisme terapung melayang-layang didalam air yang pergerakannya relativ pasif. Berdasarkan ukurannya plankton dibagi atas :

- Ultraplankton yang ukurannya kurang dari 2 milimikron

- Nanoplankton yang ukurannya berkisar antara 2-20 milimikron

- Mikroplankton yang ukurannya 20-200 milimikron

- Mesoplankton berukuran 2002000 milimikron

- Megaplankton yang ukurannya diatas 200 milimikron (Suin, 2002).

Dianthani (2003), berpendapat Fitoplankton adalah tumbuhan yang berukuran kecil yang hidupnya terombang ambing oleh air dan mampu berfotosintesis. Fitoplankton sebagai produsen utama diperairan, sedangkan organisme konsumen adalah Zooplankton, larva, udang, ikan, kepiting dan sebagainya. Plankton adalah organisme melayang yang pergerakannya tergantung pada arus. Berdasarkan perkembangan organisme, plankton dibagi 2 yaitu :

- Holoplankton yaitu organisme yang selama hidupnya sebagai plankton

- Meroplankton yaitu hanya sebagian dari hidupnya sebagai plankton, misalnya larva udang. Berdasarkan plankton ada 2 yaitu :

a) Net Plankton yaitu plankton yang dapat dijaring dengan jala plankton b) Nannoplankton yaitu plankton yang tidak dapat dijaring dengan jala plankton. Plankton yang berukuran besar biasanya tertangkap oleh jaring yang terdiri dari 2 kelompok besar yaitu Diatom dan Dinoflagellata. Diatom hidup diair tawar dan laut, juga diatas tanah-tanah basah, terpisah-pisah atau hidup berkoloni dan tidak memiliki alat gerak. Dinoflagellata dicirikan oleh sepasang flagel yang digunakan untuk bergerak dalam air dan tidak memiliki kerangka luar (Nyibakken,1992).

Plankton ( Flora dan Fauna ) dapat dijadikan indicator pencemaran. Keanekaragaman flora dan fauna ekosistem danau tinggi menandakan kualitas air danau tersebut belum tercemar, tetapi sebaliknya Fitoplankton akan menghasilkan oksigen dari proses fotosintesis yang mana oksigen ini akan membantu memurnikan air karena pencemaran. Pencemaran juga tidak dapat membunuh Zooplankton, tetapi dapat menurunkan tingkat oksigen terlarut atau merusak sumber makanannya. Sastrawijaya (1991) berpendapat bahwa plankton dapat dijadikan sebagai indikator biologis pencemaran sungai, hal ini dapat diamati dari keanekaragaman spesies atau diversitas dan laju pertumbuhan struktur. Jika keanekaragaman plankton di ekosistem tinggi menandakan kualitas air tersebut baik, tapi sebaliknya jika keanekaragaman sedikit menandakan airnya tercemar. Fitoplankton dan Zooplankton terapung dalam perairan. Siklus hidup fitoplankton yang pendek menyebabkan fitoplankton dan zooplankton cepat sekali memberikan reaksi terhadap perubahan kualitas air yang disebabkan oleh pencemaran (Sastrawijaya,1991).

Untuk mengetahui jenis Plankton yang terdapat di Danau Kandih, Desa Salak, Kota Sawahlunto dan mengetahui Komposisi Plankton yang terdapat di 
Danau Kandih, Desa Salak, Kota Sawahlunto.

\section{METODOLOGI PENELITIAN}

Penelitian ini dilakukan dengan survey deskriptif, pengambilan sample dilakukan langsung dilapangan dengan menempatkan 4 stasiun penelitian. Penetapan dilakukan yaitu stasiun I pada Batang Ombilin, stasiun II pada aliran masuk dari Sungai Batang Ombilin, stasiun III dekat keramba, stasiun IV di tempat pariwisata. Pada masing - masing stasiun dibuat 3 titik pengambilan sampel. Alat dan bahan yang digunakan dalam penelitian ini adalah net plankton (No.25), thermometer $\mathrm{Hg}$, botol film ukuran $25 \mathrm{ml}$, seperangkat mikroskop listrik monokuler, $\mathrm{pH}$ meter, kamera, pipet tetes, gelas ukur, kaca objek, kaca penutup, ember plastik 10 l, gabus. Kertas label, stop watch, selotip, labu ukur, pipet volumetrik, gelas piala, tabung uji $25 \mathrm{ml}$, spektrofotometer, timbangan analitik, buret $50 \mathrm{ml}$, labu elemeyer asah bertutup $250 \mathrm{ml}$, oven, kaca arloji, termometer, barometer, pengaduk, botol pereaksi dan alat tulis lain.

Bahan yang digunakan adalah Formalin 40\%, larutan penjerap tetrakloromerkurat $0,04 \%$, larutan induk natrium metabisulfit, larutan standar natrium metabisulfit, larutan induk iod $0,1 \mathrm{~N}$, larutan induk iod $0,01 \mathrm{~N}$, larutan indikator kanji, larutan asam klorida, larutan induk natrium tio sulfat $0,1 \mathrm{~N}$, Larutan natrium tio sulfat $0,01 \mathrm{~N}$, larutan asam klorida $1 \mathrm{M}$, larutan asam sulfamat $0,6 \% \mathrm{~b} / \mathrm{v}$, larutan asam fosfat $3 \mathrm{M}$, larutan induk pararosalanin hidroklorida $0,2 \%$, larutan formaldehida $0,2 \% \mathrm{v} / \mathrm{v}$, larutan penyangga asetat 3M. Pengambilan sample dilakukan pada stasiun yang telah ditetapkan dengan menimba 101 air yang diambil dengan ember, kemudian disaring dengan net plankton. Sampel yang tersaring dimasukkan kedalam botol sample, dan diberikan formalin $40 \%$ sebanyak $1 \mathrm{ml}$ untuk pengawetan. Ditutup dengan isolasi dan diberi label. Pengambilan sample dilakukan satu kali pada pukul 09.00 WIB. Setelah pengukuran $\mathrm{pH}$, pengambilan sample tidak dilakukan pada hari hujan. Setelah sample diambil di lapangan, selanjutnya sample diidentifikasi di Laboratorium Biologi. Identifikasi dilakukan sampai tingkat genus dengan memakai buku acuan Prescot.G.W (1974), Sachlan (1974) dengan metode yang digunakan directcount (menghitung langsung) jenis dan individu dari masing-masing stasiun.

Adapun langkah -langkah identifikasi :

1. Sampel yang telah dimasukkan kedalam botol sample diberi formalin $4 \%$ dibawa kelaboratorium Biologi STKIP

2. Sampel air dikocok hingga homogen dan diambil sebanyak 1 $\mathrm{ml}$ atau 20 tetes dengan menggunakan pipet tetes dan diteteskan kedalam kaca objek kemudian ditutup dengan cover glass

3. Diamati dibawah mikroskop secara zig - zag sehingga semua sampel pada objek glass terhitung semua Untuk tetes ke-2 sampai ke-10 lakukan cara 1-3 diatas

4. Fitoplankton yang ditemukan dikelompokkan sampai tingkat genus dengan berpedoman pada buku acuan dengan cara membandingkan deskripsi atau ciri-ciri sample dengan gambar yang ada dibuku acuan sebagai brikut:

- Bold, H.C and M.J. Wynne. 1985. Introduction to the Algae. 2 edition Prentice Hall inc. Englewood Clifft. New York. 
- $\quad$ Edmondson, W.T. 1966. Fresh Water Biology. John Wiley and Sons, Inc. New York.

- Pennak, R.W. 1978. Fresh-Water Invertebrates of The United States. John Wiley And Sons, Inc. New York.

- Sachlan, M. 1974. Planktologi. Corespondensi Cour Center. Jakarta.

- Prescott, G.W. 1978.

Algae of the Western Lake Area Revised Edition. W.M.C Brown Company Publisher and Dubuque Lowa.Prescott. G.W. 1961. Indonesian Desmid. Hydrobiologycal.XVII

- Smith, G.M. 1950. The Freshwater Algae of the United States.2 ed. M.C. Graw Hill Book Company Inch. New York.

Kemudian hitung jumlah individu masing-masing genus tersebut. Sebelum sample diambil untuk di identifikasi maka terlebih dahulu diketahui kualitas air Danau Kandih tersebut dengan langkah-langkah sebagai berikut :

1. Pengukuran Suhu

Pengukuan suhu dilakukan pada pukul 09.00 WIB, suhu diukur dengan menggunakan thermometer $\mathrm{Hg}$. Termometer dimasukkan kedalam air pada masing-masing yang telah ditetapkan selama 5 menit, catat angka yang ditunjukan thermometer sebagai suhu air.

2. Pengukuran $\mathrm{pH}$

Kadar asam diukur dengan $\mathrm{pH}$ meter pada pukul 09.00 WIB, pH meter dimasukkan dalam air dan biarkan angkanya kemudian catat angka yang ditujukan pada $\mathrm{pH}$ meter sebagai $\mathrm{pH}$ air (Michael,1984).

\section{Pengukuran Kekeruhan}

Ambil sample air pada masingmasing stasiun dengan menggunakan botol film dan diisi penuh, kemudian sample air tadi dibawa kelaboratorium.

4. Karbondioksida Bebas

Air ampel dimasukkan kedalam botol volume $250 \mathrm{ml}$. Kemudian masukkan sebanyak $100 \mathrm{ml}$ sample kedalam elemeyer dan tambahkan 10 tetes penolptelein (pp) kedalam air sample tersebut. Apabila air sample berubah menjadi merah jambu (pink) berarti air sample tidak mengandung $\mathrm{CO} 2$ dan kosentrasi $\mathrm{CO} 2$ nya rendah, maka tidak perlu dilakukan titrasi. Bila air sample tidak berubah maka titrasi dapat dilakukan dengan menggunakan $\mathrm{NaOH} \quad 0,02 \quad \mathrm{~N}$ sampai air sample berubah tepat merah jambu (pink). Hitung berapa $\mathrm{ml} \mathrm{NaOH}$ yang terpakai. Ulangi pengukuran sebanyak dua kali (jumlahkan $\mathrm{ml} \mathrm{NaOH}$ yang terpakai kemudian rata-ratakan). Volume $\mathrm{NaOH}$ yang terpakai dikali sepuluh sama dengan kosentrasi $\mathrm{CO} 2$ bebas dalam satuan ppm (Anonimus,2000).

5. Sulfur

$\begin{array}{ll}\text { Gas sulfur dioksida } & \begin{array}{r}\text { diserap } \\ \text { darutan }\end{array}\end{array}$ tetrakloromerkurat membentuk senyawa komplek diklorosulfonatomerkurat. Dengan manambahkan larutan pararosalin dan formaldehida kedalam senyawa diklorosulfonatomerkurat maka terbentuk senyawa peraeosalin metil sulfonat yang bawarna ungu.Kosentrasi larutan diukur pada panjang gelombang 550nm (SNI, 2005) 
Untuk menganalisa jumlah individu digunakan rumus

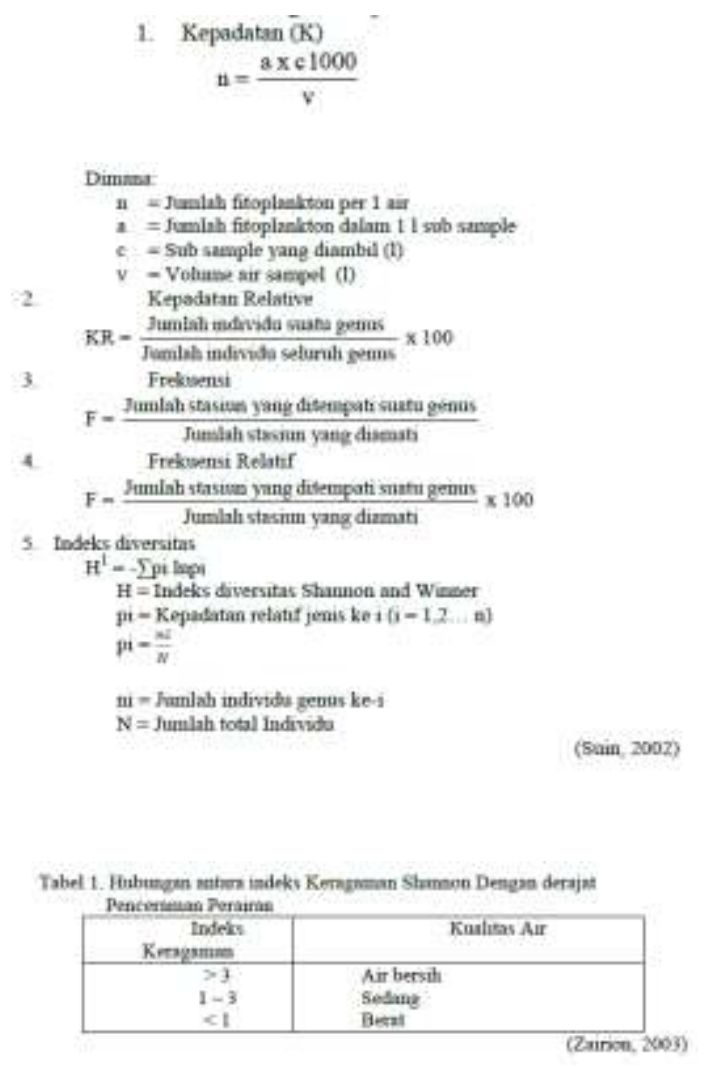

\section{HASIL DAN PEMBAHASAN}

Dari penelitian yang telah dilakukan tentang komposisi plankton di Danau Kandis, Desa Salak, Kota Sawahlunto didapatkan hasil seperti Tabel 2. dibawah:

Tabel 2 Komposisi (und) planstou di Danan Kandis, Desa Salnik, Kota

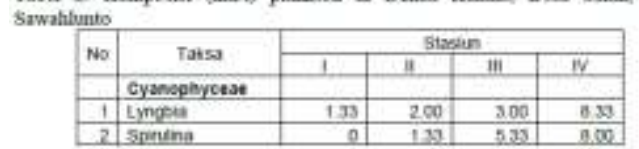

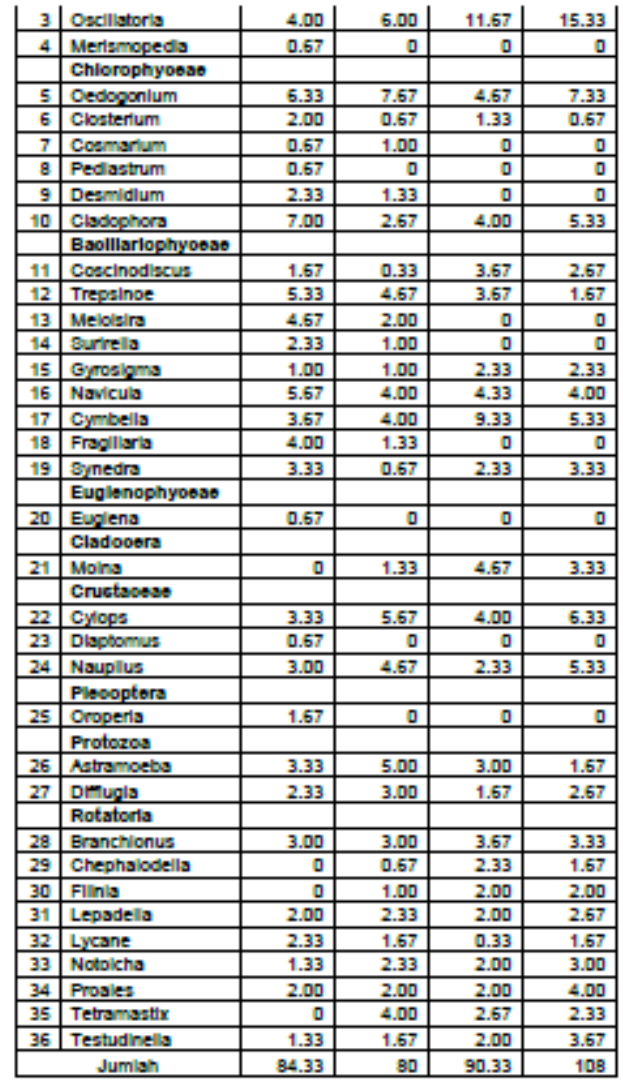

Dari Tabel 2. diatas dapat dilihat komposisi plankton yang terdapat di Danau Kandis, Desa Salak, Kota Sawahlunto, didominasi oleh kelompok fitoplankton baik dari jumlah individu atau jumlah variasi jenis nya. Jenis fitoplankton yang ditemukan terdapat 20 jenis, sedangkan zooplankton terdapat 12 jenis. Hal ini disebabkan karena Danau Kandis ini termasuk Danau yang baru penggunaannya setelah dimanfaatkan sebagai tambang batu bara, sehingga pertumbuhan zooplankton masih termasuk baru dan pertumbuhan zooplankton tersebut lebih lambat dibandingkan dengan pertumbuhan fitoplankton.

Tidak semua plankton ditemukan pada masing-masing stasiun. Beberapa jenis plankton hanya ditemukan pada stasiun I, yang merupakan sumber air dari Danau Kandis yaitu pada Batang Ombilin. Jenis yang ditemukan pada stasiun I ini adalah: Merismopedia, Pediastrum, Euglena, Diaptomus dan 
Oroperla. Merismopedia, Pediastrum dan Euglena merupakan kelompok alga yang hidup pada perairan yang bersih (Presscot, 1978). Edmondson (1966) menjelaskan jenis Diaptomus biasanya hidup pada perairan yang bersih atau perairan yang tercemar ringan oleh limbah organik. Pennak (1978) menjelaskan jenis dari Oroperla ini biasa hidup pada daerah yang berbatu. Seperti yang terdapat pada stasiun I yang merupakan daerah aliran Batang Omblin yang dasarnya berbatu dan berpasir. Sedangkan jenis plankton yang menempati 2 stasiun yaitu stasiun I dan stasiun II adalah Cosmarium, Desmidium, Meloisira, Surirella dan Fragillaria. Menurut Usman (2004) jenis tersebut biasa hidup pada perairan yang bersih sampai tercemar ringan. Jenisjenis plankton yang menempati 3 stasiun yaitu pada stasiun II, stasiun III dan stasiun IV adalah Spirulina, Moina, Chephalodella, Filinadan Tetramastix. Jenis ini tidak ditemukan pada air masuk ke Danau Kandis tersebut.

\section{Kemungkinan} jenis ini merupakan masukan dari sumber air yang lain dari Danau Kandis. Dan menurut Pennak (1978) jenis dari Chephalodella, Filina dan Tetramastix merupakan jenis yang biasa hidup pada perairan yang tercemar. Sedangkan jenis Spirulina juga merupakan alga yang biasa hidup pada perairan yang tercemar (Presscot, 1978). Jenis-jenis fitoplankton yang menempati keseluruhan stasiun adalah Lyngbia, Oscillatoria, Oedogonium, Closterium, Cladophora, Coscinodiscus, Tepsinoe, Gyrosigma, Navicula, Cymbella dan Synedra. Jenisjenis tersebut merupakan kelompok alga yang memiliki penyebaran yang luas dan mampu hidup pada perairan bersih sampai tercemar berat (Usman,2004). Sedangkan jenis-jenis zooplankton yang ditemukan pada ke 4 stasiun tersebut adalah Cylops, Nauplius, Astramoeba,
Difflugia, Branchionus, Lepadella, Lycane, Notholca, Proales dan Testudinella. Kelompok ini memiliki penyebaran yang luas. Menurut Pennak (1978) beberapa jenis tersebut bisa hidup pada berbagai tipe perairan.

Tabel 3. Kerapatan (K), Kerapatan Relatif (KR) dan Indeks Diversitus (H) Plankton di Danau Kandis Kota Sawahlunto

\begin{tabular}{|c|c|c|c|c|c|c|c|c|c|c|c|c|c|}
\hline \multirow{3}{*}{ No } & \multirow{3}{*}{ Takks } & \multicolumn{12}{|c|}{ stasinn } \\
\hline & & \multicolumn{3}{|c|}{ | } & \multicolumn{3}{|c|}{ II } & \multicolumn{3}{|c|}{ III } & \multicolumn{3}{|c|}{ NV } \\
\hline & & $\bar{K}$ & KR & plingl & K & KR & dind & K & KR & plingl & k & KR & pi / nol \\
\hline & Cranoohycsas & & & & & & & & & & & & \\
\hline 1 & Lingóa & 0.33 & 1.58 & -0.0656 & 0.50 & 2.50 & .0 .0322 & 0.75 & 3.32 & -0.1131 & 208 & 7.72 & 0.0 .1977 \\
\hline 2 & Solinulina & 0 & 0 & & 0.33 & \begin{tabular}{|l|}
1.67 \\
\end{tabular} & .0 .0682 & 1,33 & 5.90 & -0.1671 & 200 & 7.41 & 0.1528 \\
\hline 3 & Oscillatoria & 1.00 & 4.74 & -0.1446 & 1.50 & 7.50 & -0.1943 & 292 & 1292 & -0.2644 & 3.83 & 14.20 & .02772 \\
\hline \multirow[t]{2}{*}{4} & Merismopeda & 17 & 0.79 & -0.0383 & 0 & 0 & & 0 & 0 & & 0 & 0 & \\
\hline & Chlorophycese & & & & & & & & & & & & \\
\hline 5 & Oedogononium & 58 & 7.51 & -0.1944 & 1.92 & 9.58 & .0 .2247 & 1.17 & 5.17 & -0.1531 & 1.83 & 6.79 & -0.1826 \\
\hline 6 & Coctentum & 0.50 & 2.37 & -0.0887 & 0.17 & 0.83 & 0.0399 & 0.33 & 1.48 & -0.0622 & 0.17 & 0.62 & 0.0314 \\
\hline 7 & cosmantum & 0.17 & 0.79 & -0.0383 & 0.25 & \begin{tabular}{l|l|}
1.25 \\
\end{tabular} & .0 .0548 & 0 & 0 & & 0 & 0 & \\
\hline 8 & Pedxsiom & 0.17 & 0.79 & -0.0383 & 0 & 0 & & 0 & 0 & & 0 & 0 & \\
\hline 9 & Desmidlum & 0.58 & 2.77 & -0.0993 & 0.33 & \begin{tabular}{|l|}
1.67 \\
\end{tabular} & .0 .0682 & 0 & 0 & & 0 & 0 & \\
\hline \multirow[t]{2}{*}{10} & Clasbophora & 1.75 & 8.30 & -0.2066 & 0.67 & 3.33 & -0.1134 & 1.00 & 4.43 & -0.138 & 1.33 & 4.94 & -0.1486 \\
\hline & Baclliarioph & & & & & & & & & & & & \\
\hline 11 & Cosdnodsals & 0.42 & 1.98 & 0.0776 & 0.08 & 0.42 & -0.0228 & 0.92 & 4.06 & -0.1301 & 0.67 & 247 & -0.0914 \\
\hline 12 & Tressinoe & 1.33 & 6,33 & -0.1746 & 1.17 & 5.83 & -0.1658 & 0.92 & 4.06 & -0.1301 & 0.42 & 1.54 & -0.0644 \\
\hline 13 & \begin{tabular}{|l|l} 
Mejosira \\
\end{tabular} & 1.17 & 5.53 & -0.1602 & 0.50 & 2.50 & 0.0322 & 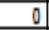 & 0 & & 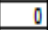 & 8 & \\
\hline 14 & Surnella & 0.58 & 2.77 & -0.0993 & 0.25 & \begin{tabular}{|l|}
1.25 \\
\end{tabular} & .0 .0548 & 0 & 0 & & 0 & 0 & \\
\hline 15 & Grosiama & 0.25 & 1.19 & -0.0526 & 0.25 & \begin{tabular}{|l|l|}
1.25 \\
\end{tabular} & .0 .0548 & 0.58 & 258 & -0.0945 & 0.58 & 2.16 & .0 .0629 \\
\hline 16 & Navicula & 1.42 & 6.72 & -0.1815 & 1.00 & 5.00 & -0.1498 & 1.08 & 4.80 & -0.1457 & 1.00 & 3.70 & -0.121 \\
\hline 17 & Cymbella & 0.92 & 4.35 & -0.1363 & 1.00 & 5.00 & -0.1498 & 2.33 & 10.33 & -0.2345 & 1.33 & 4.94 & -0.1486 \\
\hline 18 & Fragl|lara & 1.00 & 4.74 & 0.1446 & 0.33 & \begin{tabular}{|l|}
1.67 \\
\end{tabular} & .0 .0682 & 0 & 0 & & 0 & 0 & \\
\hline \multirow[t]{2}{*}{19} & Synedra & 0.83 & 3.95 & -0.1277 & 0.17 & 0.83 & .0 .0399 & 0.58 & 258 & -0.0915 & 0.83 & 3.09 & -0.1074 \\
\hline & Euglenoph & & & & & & & & & & & & \\
\hline \multirow[t]{2}{*}{20} & Eugena & 0.17 & 0.79 & -0.0383 & 0 & 0 & & 0 & 0 & & 0 & 0 & \\
\hline & \begin{tabular}{|cl} 
Cladocosera \\
\end{tabular} & & & & & & & & & & & & \\
\hline \multirow[t]{2}{*}{21} & Mona & & 0 & & 0.33 & \begin{tabular}{|l|}
1.67 \\
\end{tabular} & .0 .0682 & 1.17 & \begin{tabular}{|l|}
5.17 \\
\end{tabular} & $\begin{array}{r}-0.1531 \\
\end{array}$ & 0.83 & 3.09 & -0.1074 \\
\hline & Crustices9 & & & & & & & & & & & & \\
\hline 22 & Cylo06 & 0.83 & 3.95 & $\begin{array}{l}0.1277 \\
\end{array}$ & 1.42 & \begin{tabular}{|l|}
7.08 \\
\end{tabular} & -0.1875 & 1.00 & \begin{tabular}{ll|l}
4.43 \\
\end{tabular} & -0.138 & 1.58 & 5.86 & -0.1663 \\
\hline 23 & \begin{tabular}{|l} 
Dasolomus \\
\end{tabular} & 0.17 & 0.79 & 0.0383 & 4 & 0 & & 0 & 0 & & 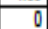 & 0 & \\
\hline \multirow[t]{2}{*}{24} & Naupl|lis & 0.75 & 3.56 & -0.1187 & 1.17 & 5.83 & -0.1658 & 0.58 & 258 & -0.0915 & 1.33 & 4.94 & 0.148 \\
\hline & Plecopter: & & & & & & & & & & & & \\
\hline \multirow[t]{2}{*}{25} & Oroperta & 0.42 & 1.98 & -0.0776 & 0 & 0 & & 0 & 0 & & 0 & 0 & \\
\hline & Protozoa & & & & & & & & & & & & \\
\hline 26 & Astramoet & 0.83 & 3.95 & $\begin{array}{l}-0.1277 \\
\end{array}$ & 1.25 & 6.25 & \begin{tabular}{|c|}
-0.1733 \\
\end{tabular} & 0.75 & 3.32 & \begin{tabular}{|c|}
-0.1131 \\
\end{tabular} & 0.42 & 1.54 & -0.0644 \\
\hline \multirow[t]{2}{*}{20} & Dinuga & 0.58 & 2.77 & $\begin{array}{r}-0.0993 \\
\end{array}$ & 0.75 & 3.75 & -0.1231 & 0.42 & 1.85 & -0.0737 & 0.67 & 2.47 & \begin{tabular}{|c|}
-0.0914 \\
\end{tabular} \\
\hline & Rotator & & & & & & & & & & & & \\
\hline 28 & & 0.75 & 3.56 & $\begin{array}{l}-0.1187 \\
\end{array}$ & 0.75 & 3.75 & -0.1231 & 92 & 4.06 & \begin{tabular}{|c|}
-0.1301 \\
\end{tabular} & 0.83 & 3.09 & 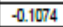 \\
\hline 29 & Chephes & 0 & 0 & & 0.17 & 0.83 & -0.0399 & 0.58 & 258 & -0.0945 & 0.42 & 1.54 & -0.0644 \\
\hline 30 & Fillina & 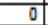 & 0 & & 0.25 & 1.25 & -0.0548 & 0.50 & 221 & -0.0844 & 0.50 & 1.85 & -0.0739 \\
\hline 31 & Lepade & 0.50 & 237 & -0.0887 & 0.58 & 2.92 & -0.1031 & 0.50 & 221 & -0.0844 & 0.67 & 2.47 & -0.0914 \\
\hline 32 & Lycane & 0.58 & 2.77 & $\begin{array}{r}-0.0993 \\
\end{array}$ & 0.42 & 2.08 & -0.0907 & 0.08 & \begin{tabular}{|l|}
0.37 \\
\end{tabular} & -0.0207 & 0.42 & 1.54 & -0.0644 \\
\hline+ & Noto & 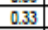 & 1.58 & -0.0656 & 0.58 & 2.92 & -0.1031 & & 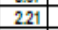 & -0.0844 & 0.75 & 278 & $\begin{aligned}-0.099 \\
\end{aligned}$ \\
\hline 34 & Prodes & 0.50 & 237 & -0.0887 & 0.50 & 2.50 & -0.0922 & 501 & 221 & -0.0844 & 1.00 & 3.70 & -0.1221 \\
\hline 35 & Tetramast & 0 & 0 & & 1.00 & 5.00 & -0.1498 & 0.67 & 2.95 & -0.104 & 0.58 & 2.16 & -0.0829 \\
\hline 36 & Testudnel & 0.33 & 1.58 & -0.0656 & 0.42 & 2.08 & -0.0907 & 0.50 & 221 & -0.0844 & 0.92 & 3.40 & -0.1148 \\
\hline & Jun & 08 & 100 & $\begin{array}{r}3.2607 \\
\end{array}$ & 20 & 100 & -3.19991 & 22.58 & 100 & -3.0706 & 27.00 & 100 & \begin{tabular}{|l|}
-3.0454 \\
\end{tabular} \\
\hline & Indeks alversitas & & $\frac{13.260}{3.200}$ & & & 3.1991 & & & 3.0706 & & & 3.0454 & \\
\hline
\end{tabular}

Pada Tabel 3. diatas didapatkan kerapatan plankton tertinggi ditemukan pada stasiun IV yaitu sebanyak 27 ind/L. Hal ini disebabkan karena banyaknya penumpukan limbah organik yang masuk ke Danau Kandis yang berasal dari dedaunan disekitar stasiun tersebut. Selanjutnya terdapat pada stasiun III sebanyak 22,8 ind/L, Stasiun I sebanyak $21,08 \mathrm{ind} / \mathrm{L}$ dan yang terendah terdapat pada stasiun II sebanyak 20 ind/L. Jenis yang memiliki kepadatan yang paling 
tinggi ditemukan pada jenis Oscillatoria yaitu sebesar 3,83 ind/L. Oscillatoria ini dapat hidup diberbagai tipe perairan, sekalipun perairan yang extreme sekalipun seperti suhu yang tinggi dan DO yg terendah atau nol (Reynolds, 1984).

Total kelimpahan adalah sebanyak 90,66 individu $/ 1$, ini menandakan bahwa perairan danau Kandi kurang subur. Prescott (1975) menyatakan suatu perairan dapat diklasifikasikan berdasarkan kelimpahan fitoplankton, diantaranya adalah perairan oligotrof (kesuburan rendah), ditandai dengan kelimpahan individu kecil dari puluhan ribu individu perliter, perairan mesotrof (kesuburan sedang), yaitu kelimpahan besar dari puluhan ribu sampai ratusan ribu individu perliter dan perairan eutrof (sangat subur) jika kelimpahan fitoplankton jutaan individu perliter.

Dilihat dari nilai indeks diversitas pada setiap stasiun pengamatan didapatkan nilai antara 3,0454 - 3,2607. Nilai ini lebih besar dari 3, maka perairan ini termasuk perairan yang bersih. Menurut Zairion (2003) berdasakan tabel indeks diversitas Shannon-winner yang nilainya besar dari 3, maka perairan tersebut termasuk perairan yang bersih. Dari pengukuran faktor fisika kimia air seperti terlihat dalam Tabel 4. dari masing-masing stasiun pengamatan diketahui hasil pengukuran suhu, suhu tertinggi didapatkan pada stasiun IV yaitu $310 \quad \mathrm{C}$ dan suhu terendah didapatkan pada stasiun II yaitu $260 \mathrm{C}$. Suhu di Danau Kandi sudah cukup ideal untuk pertumbuhan fitoplankton. Mathew (1975) menyatakan suhu optimum untuk pertumbuhan plankton antara 26-280C. Michael (1994) menyatakan suhu diperairan daerah tropis berkisar antara 23-320 C. Hasil pengukuran $\mathrm{pH}$ air di Danau Kandi tertinggi didapatkan pada stasiun I yaitu sebesar 7,1 dan terendah didapatkan pada stasiun IV yaitu 6,4. Angka ini sudah mendukung untuk kehidupan fitoplankton. Derajat keasaman yang baik untuk pertumbuhan fitoplankton berkisar antara 5,5-8,5 (Smith, 1950). Kekeruhan di Danau Kandi tertinggi didapatkan pada stasiun IV yaitu sebesar 52,0 NTU dan terendah pada stasiun I yaitu sebesar 8,0 NTU. Angka ini menunjukkan bahwa kondisi air danau Kandi sangat keruh.

Berdasarkan peraturan MENKES RI No. 416 MENKES / IX / 1990 dalam Okwiyanita, 2007 nilai maksimal untuk kekeruhan yaitu 25 NTU. Nybakken (1992) menyatakan kekeruhan menyebabkan terhalangnya cahaya matahari untuk masuk kedalam air yang akan menggangu terjadinya proses fotosintesis dan juga akan menyebabkan terganggunya pertumbuhan fitoplankton. Kadar oksigen terlarut tertinggi didapatkan pada stasiun II yaitu sebesar $6,73 \mathrm{mg} / \mathrm{l}$ dan terendah didapatkan pada stasiun III yaitu sebesar $3,72 \mathrm{mg} / \mathrm{l}$. Kadar Oksigen terlarut di Danau Kandi udah cukup ideal untuk pertumbuhan fitoplankton. Kordi (1996) menyatakan kisaran oksigen ideal untuk kehidupan organisme perairan adalah 5-7 mg/l. Karbondioksida bebas tertinggi didapatkan pada stasiun II yaitu sebesar $1,85 \mathrm{mg} / \mathrm{l}$ dan terendah didapatkan pada stasiun III yaitu sebesar $1,49 \mathrm{mg} /$. Nitrogen air di Danau Kandi terrtinggi didapatkan pada stasiun IV yaitu sebesar $2,15 \mathrm{mg} / \mathrm{l}$ dan terendah didapatkan pada stasiun II yaitu sebesar $1,32 \mathrm{mg} / \mathrm{l}$. Angka ini sudah mendukung untuk kehidupan fitoplankton. Chu (1943) menyatakan alga khususnya fitoplankton dapat tumbuh optimal pada kandungan nitrat sebesar 0.0009-3,5 mg/l. Pada kosentrasi dibawah $0,01 \mathrm{mg} / \mathrm{l}$ atau diatas $4,5 \mathrm{mg} / 1$ nitrat dapat berupa faktor pembatas. Sulfur di Danau Kandi berkisar antara 
0,172-0,497 mg/l. Berdasarkan PERGUB baku mutu sulfur di air adalah $2 \mathrm{mg} / \mathrm{l}$.

\section{DAFTAR PUSTAKA}

Anonimus. 2008. Dokumen Upaya Pengelolaan Lingkungan (UPL) Upaya Pemantauan Lingkungan (UKL). Pemkot Sawahlunto. Anonimus. 2010. Danau Kandih / a/i.html. Diakses 15 Mei 2010.

Anwar, J dkk. 1984. Ekologi Ekosistem Sumatera. Yogjakarta: Gadjah Mada University Press. Arif, A. 1995. Pengantar Lingkungan II. Institut Keguruan dan Ilmu Pendidikan Padang.

Dianthani, P. 2003. Identifikasi Fitoplankton Di Perairan Muara Badak Kalimantan Timur. Skripsi IPB Bogor.

Damarring, T, W. 2006. Pengelolaan Sumber Daya Alam Danau.Pasca Sarjana Biologi UI Jakarta.

Djuhanda, T. 1980. Kehidupan Dalam Setetes Air dan Beberapa Parasit Pada Manusia. ITB Bandung.

Ediyarman. 2009. Laporan Pemantauan Kualitas Air Semester Tahun 2009. BLH Kota Sawahlunto.

Edmondson, W.T. 1966. Fresh Water Biology. John Wiley and Sons, Inc. New York

Fachrul, M.F. 2006. Metoda Sampling Ekologi. Jakarta: Bumi Aksara.

Fardias, S. 1992. Populasi Air dan Udara. Jakarta: Kanisius.

Herawati, V. 2008. Analisis Kesesuaian Perairan Segara Anakan Kabupaten Cilacap Sebagai Lahan Budidaya Kerang Totok (Polymesoda erosa) Ditinjau Dari Aspek Produktifitas Primer Menggunakan Pengindraan Jauh. Pascasarjana UNDIP.
Kordi, K. M. G. 1996. Parameter Kualitas Air. Surabaya: Karya Anda.

Michael,P. 1984. Metode Ekologi untuk Penyelidikan Ladang dan Laboratorium. Jakarta : UI Press.

Nontji, A. 1993. Laut Nusantara. Jakarta: Djambatan.

Nybakken, W. J. 1992. Biologi Laut Suatu Pendekatan Ekologis. Jakarta: Gramedia.

Odum, P. E. 1998. Dasar-Dasar Ekologi. Jogjakarta: Gadjah Mada University Press.

Palar, H. 1994. Pencemaran dan Toksilogi Logam Berat. Jakarta: Rineka Cipta.

Pennak, R.W. 1978. Fresh-Water Invertebrates of The United States. John Wiley And Sons, Inc. New York.

Sachlan, M. 1974. Planktologi. Corespondensi Cour Center. Jakarta.

Sastrawijaya, A.T. 1991. Pencemaran Lingkungan . Jakarta: Rineka Cipta

SNI. 2005. Cara Uji Kadar Sulfat Dioksida (SO2) dengan Metode Pararosanilin Menggunakan Spektrofotometer. Udara Ambien Bagian 7.

Smith, G.M. 1950. The Freshwater algae of United States. 2nd Ed. Mc Graw Hill Book Co.Inc. New York.

Suin, M.N. 2002. Metode Ekologi. Andalas University press .

Tjiptosoepomo, G. 1981. Taksonomi Tumbuhan Rendah. Jakarta: Bhantara Karya Aksara.

Welch, E. 1980. Limnolog.Mc.GrawHill. Book Company. New York. 
Zairion. 2003. Makalah kursus DasarDasar Amdal untuk Dosen-Dosen PTN dan PTS Sesumatera.PS Analisis Lingkungan-PMIPA IPB Bogor 